\title{
The Effect of the Collaborative Online Learning Model on Students' Learning Process and Performance in an Open University
}

\author{
Dewi Padmo ${ }^{1, *}$ Suciati Sastro ${ }^{2, K e t u t ~ B u d i a s t r a ~}{ }^{3}$
}

\author{
${ }^{1}$ Universitas Terbuka 1 \\ ${ }^{2}$ Universitas Terbuka 2 \\ ${ }^{3}$ Universitas Terbuka 3 \\ *Corresponding author. Email: dewi@ecampus.ut.ac.id
}

\begin{abstract}
The use of collaborative online learning models is expected to develop teamwork and student participation, which is a part of 'non-cognitive skills' that are needed for self-development. The quasi-experimental research on the collaborative online learning model aimed to analyze its effect on students' learning processes and students' outcomes; and to analyze student experiences in implementing such a model. The study sample was a group of 85 students from an Open University who participated in the online tutorial and consisted of 14 teams. The data on students' learning processes and students' outcomes was taken from the online course on Analytic Learning and from their responses to an online questionnaire, and the results obtained were analyzed. In terms of students' performance, the correlation between the number of posts and student scores on the online tutorial indicated a positive correlation $(\mathrm{r}=0.506, \mathrm{p}$-value 0.01$)$, and the correlation between the number of posts with the final score also indicated a positive correlation $(r=0.348, p$-value 0.01). The results showed a significant difference in the number of posts in the online tutorial in terms of the region of origin/student's domicile $(\mathrm{p}$-value $=0.005)$. There were ten aspects of collaboration measured through online questionnaires in the study. The results of the measurements on the 10 aspects showed that the average rating of respondents was above 4.0 (strongly agree to strongly disagree) for 9 aspects, and for one, it was 3.90.
\end{abstract}

Keywords: collaborative online learning model, online learning, distance education

\section{INTRODUCTION}

The collaborative learning activity is one of the learning strategies in online learning that is expected to build good interactions between students. Harasim (2012) suggests that the theory of collaborative online learning provides a learning model that supports students to work together to create knowledge, discover and explore innovation, look for concepts needed to solve problems. Dillenbourg (2002) suggests that the design of computer-based collaborative learning requires a structure of activities that integrates individual activities and collaborative activities using both face-to-face communication and computer-based communication. The same idea was stated by Gibson (2013) that the design and development of an online learning environment must be associated with several elements such as self-reflection, authentic learning, active learning, and collaborative learning. With online learning, the asynchronous discussion forum is a widely used method. Related to the asynchronous discussion, Luhrs and Salas (2016) suggested that asynchronous discussion forums in online learning can be fully utilized. Participants in online discussions need to pay attention and understand the dynamics of interaction and collaboration among participants and the factors that influence them.

In terms of e-learning, Demsey and Van Eck (2012) suggest that e-learning is characterized by two kinds of phenomena as the functional architecture that are using a variety of collaborative or interactive activities, and the use of technology is designed to achieve learning outcomes. With technological capabilities, online learning by means of a proper learning design can create 
active learning and facilitate the involvement of students, providing a diverse learning experience (Simonson, Smaldhino, Albright \& Zvacek, 2012). Wang (2007) suggests that the involvement of active learning through interaction between students in the learning process or learning community is very important in improving the quality of their learning. Furthermore, Demsey and Van Eck (2012) suggest that online learning can be done in a synchronous or asynchronous manner or a combination of both, allowing students to interact with one another using the learning management system (LMS).

\subsection{Collaborative Online Learning Design}

In collaborative online learning activities, students can use various media to interact, such as wikis, or even audio/video conferencing technology. In an online tutorial where students do not meet in person, the media for interacting between students becomes very important. Chalin, Chen, and Chan (2009) suggested that interactive use of technology in the learning process should be able to improve communication between individuals and groups and between individuals, where the contribution of each individual is valued. Demsey and Van Eck (2012) suggest the importance of paying attention to the achievement of learning outcomes associated with the use of a combination of technologies and supported by good instructional design. This is in line with Maurino (2007) who argues that adequate communication and learning systems in distance education should enable students to communicate intensely with instructors and other students. According to Brereton, Cannon, Mabogunje, and Leifer (1996) each individual in a team of a collaborative online learning model is designed to have an attitude and ability in expressing ideas, listening, and also negotiating.

Cross (2011) suggests that the process of designing carried out by a team is a fairly complex process with a variety of activities that can take place at the same time. Tracey (2015) also suggested that collaborative process and product design in the team was carried out through the presentation of ideas, discussions, improvements, and also consensus. Based on the results of research and expert opinion on collaborative learning, the design of collaborative online learning instruction should provide an opportunity for all team members to be able to interact using discussion forums or other communication devices.

To optimize the online learning process for Open University students, it is necessary to explore the collaborative learning model in online tutorials. Therefore, a study on the effect of the collaborative online learning model in an Open University environment was conducted. There were several questions to explore in this study. They are: How does collaborative online learning develop cooperation, process effectiveness, and student learning outcomes?
How does collaborative online learning processes contribute to student's experience of learning? Thus, this study aims to analyze the effect of collaborative online learning on students' learning processes and students' outcomes, and analyze student experiences in implementing a collaborative online learning model.

\section{METHODS}

The quasi-experimental research on the collaborative online learning model aimed to analyze its effect on students' collaboration aspects. This study was a one group a pretest posttest. The intervention in this study was an implementation design of collaborative online learning model. There were ten aspects of collaboration measured through online questionnaires in the study. The teams' collaboration aspects was measured two times, before the intervention was given and after the intervention was given.

\subsection{Participants}

The study involved three online classes with a total of 85 graduate students from the Universitas Terbuka as a participants of this study. The students who participated in this study were recruited from the course "Education Innovation Diffusion" which was delivered online. In each class, there were about 26 to 30 students grouped into 4 or 5 students per team. In total, 14 teams participated in this study.

\subsection{Intervention design}

The design of the collaborative online learning model was created based on the standard online tutorial design for post-graduate UT's students. The standardized design of UT's online tutorial for postgraduate students consists of 12 online sessions. Collaborative activities are not yet employed and integrated into UT's online tutorial, therefore, the study focused on designing and implementing a collaborative online learning model. In the design, the students have to participate in a "general discussion forum with all students in the online tutorial class" and a "team discussion forum". However, it was designed that the students have an intense discussion in a "team discussion forum" to complete their collaborative tasks. The design of collaborative online learning in this study is shown in Figure 1. 


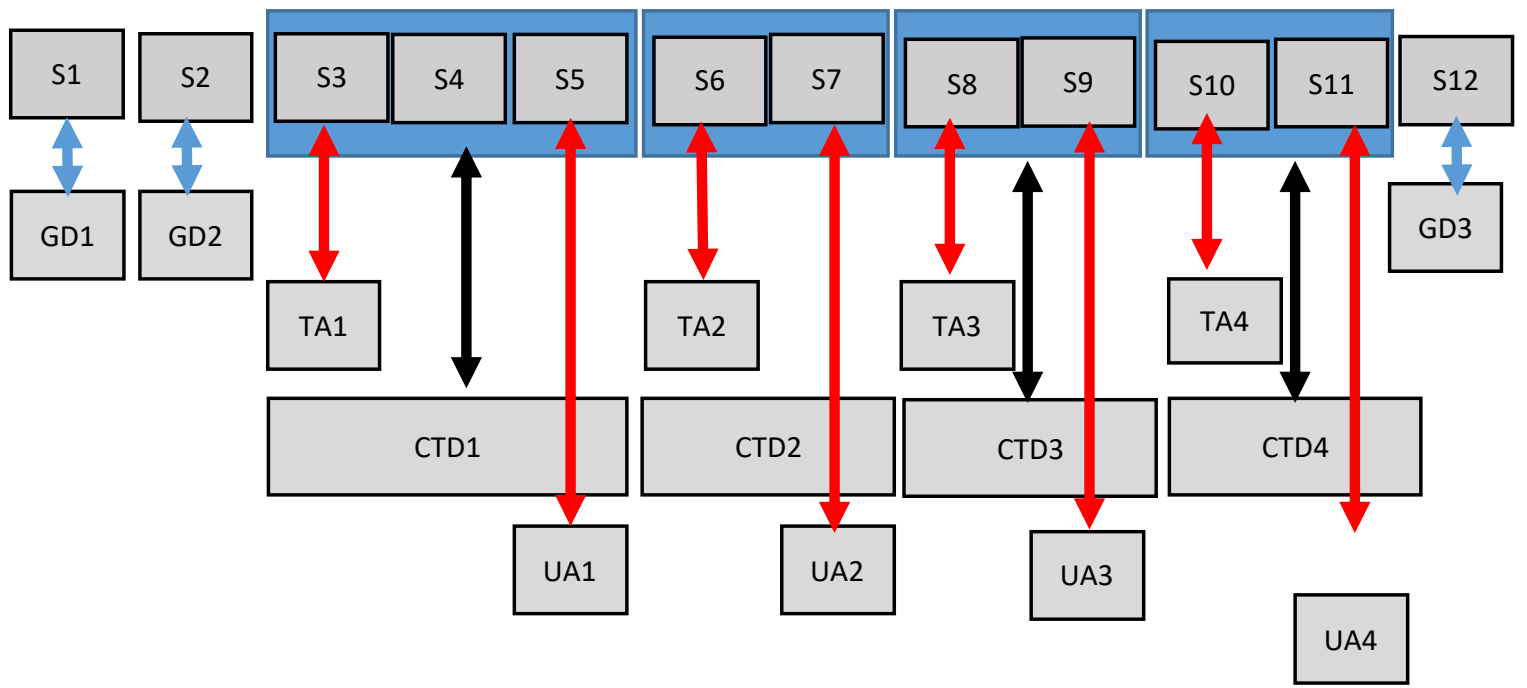

Figure 1 The collaborative online learning design model

Note:

$\mathrm{S}=$ Session

$\mathrm{GD}=$ General Discussion

TA $=$ Team Assignment

$\mathrm{CTD}=$ Collaborative Team Discussion

$\mathrm{UA}=$ Upload Assignment

\subsection{Data collection}

The study was quasi-experimental. Data was collected both quantitatively and qualitatively. Quantitative data is obtained using online questionnaires. The questions included target and work mechanism, team strategy, communication, freedom of expression, division of tasks, quality of work, team decisions, smooth workflow, individual contribution, and level of satisfaction. An online questionnaire on team collaboration having a five-point Likert scale starting from strongly agree, agree, not sure, disagree, and strongly disagree was used. The students filled the online questionnaire twice after the team worked together to complete collaborative tasks at a certain period. The open questions were collected to explore information related to the implementation of online learning which included constraints, and experiences involved in participating in collaborative online learning. In terms of students' performance, data was collected focusing on the learning analytics of the process of online tutorials and from students' grades after they completed the online course.

\section{FINDING AND DISCUSSION}

The students of three online courses as respondents who participated in this study were from tree regions in Indonesia i.e. Jakarta, Tangerang, and East Java, as shown in Table 1.
Table 1. Number of respondents per regions

\begin{tabular}{llcc}
\hline No & Regions & $\begin{array}{c}\text { Number of } \\
\text { Students }\end{array}$ & Percentage \\
\hline 1 & Jakarta & 54 & 60.67 \\
2 & Tangerang & 14 & 15.73 \\
3 & East Java & 21 & 23.60 \\
\hline & Total & 89 & 100
\end{tabular}

\subsection{Descriptive analysis of engagement and learning outcomes}

The association of student involvement in the learning process and student learning outcomes in an online collaborative context is reported to highlight factors that are effective in online collaboration. The data is related to several aspects of the learning process, which includes the number of posts, the number of accesses, the course end score, the online tutorial score, and the final course grade, associated with gender and place of origin.

The online tutorial is divided into 12 sessions in one semester, and each session contains initiation material which includes the highlights of core content, a discussion forum to address certain aspects of education innovation and diffusion, or addressing the collaborative tasks of student workgroups. Students should add a post 
in the discussion forum for each session. A discussion forum is considered a strategic activity, in which students post their opinions, questions, suggestions, or add an encouraging comment for fellow students who seemed to be facing a difficulty in the learning process. Many also share information regarding additional complementary online material for a specific topic.

Table 2 shows that the average student posts are 9.7, and SD 7.8, meaning that all students access and participate in the discussion, at least once. Some students have up to 16 posts during the semester. In the online tutorial, it appears that in terms of content, participation in discussion forums is in the form of offering explanation and requests, questions and short responses expressing agreement, and giving support to other student ideas. This discussion forum still needs to be improved as a venue for students' discussion, to exercise critical and creative thinking for alternatives and solutions. Students' final grades indicate that most students achieve high grades $(\mathrm{M}=82.01, \mathrm{SD}=10.9)$.

Table 2. Descriptive statistics of engagement and learning outcomes

\begin{tabular}{lrrr}
\hline & \multicolumn{1}{c}{ Mean } & \multicolumn{1}{c}{ SD } & \multicolumn{1}{c}{$\mathrm{N}$} \\
\hline Number of posting & 9.71 & 7.883 & 89 \\
Number of access & 105.00 & 83.548 & 89 \\
Final course score & 81.1180 & 11.15516 & 89 \\
Online score & 71.6180 & 21.93146 & 87 \\
Final grade & 82.0152 & 10.94346 & 89 \\
\hline
\end{tabular}

\subsubsection{Correlation of Intensity of Engagement and Learning Outcomes}

The finding reveals a relationship between several measures of intensity of involvement in online tutorials and student learning outcomes. The intensity of online tutorials is represented by the frequency (times) of student access in one semester, and the number of posts in the Discussion Forum. The final score refers to the final exam score of a course. The final grade is the final course score based on scores on online tutorial, and course end score. Table 3 presents the correlations among the tested variables.

Table 3. Correlation of participation intensity in the online tutorial and learning outcomes

\begin{tabular}{|c|c|c|c|c|c|c|}
\hline & & $\begin{array}{c}\text { Numbe } \\
\text { r of } \\
\text { posting }\end{array}$ & $\begin{array}{c}\text { Numbe } \\
\text { r of } \\
\text { access }\end{array}$ & $\begin{array}{l}\text { Final } \\
\text { cour } \\
\text { se } \\
\text { score }\end{array}$ & $\begin{array}{l}\text { Onli } \\
\text { ne } \\
\text { score }\end{array}$ & $\begin{array}{c}\text { Final } \\
\text { grad } \\
\text { e }\end{array}$ \\
\hline \multirow{2}{*}{$\begin{array}{l}\text { Number } \\
\text { of pos- } \\
\text { ting }\end{array}$} & $\begin{array}{l}\text { Pears } \\
\text { on }\end{array}$ & 1 & $.758 * *$ & .137 & $\begin{array}{r}.506^{*} \\
* \\
\end{array}$ & $\begin{array}{r}.348 \\
* *\end{array}$ \\
\hline & $\begin{array}{l}\text { Correl } \\
\text { ation }\end{array}$ & & & & & \\
\hline
\end{tabular}

\begin{tabular}{|c|c|c|c|c|c|c|}
\hline & $\begin{array}{l}\text { Sig } \\
(2- \\
\text { tailed) }\end{array}$ & & .000 & .199 & .000 & .001 \\
\hline \multirow{5}{*}{$\begin{array}{l}\text { Number } \\
\text { of access }\end{array}$} & $\mathrm{N}$ & 89 & 89 & 89 & 89 & 89 \\
\hline & $\begin{array}{l}\text { Pears } \\
\text { on }\end{array}$ & $.758 * *$ & & 122 & $\begin{array}{r}402 * \\
*\end{array}$ & $\begin{array}{r}298 * \\
* \\
\end{array}$ \\
\hline & $\begin{array}{l}\text { Correl } \\
\text { ation }\end{array}$ & & & & & \\
\hline & $\begin{array}{l}\text { Sig } \\
(2- \\
\text { tailed) }\end{array}$ & .000 & & .255 & .000 & .005 \\
\hline & $\mathrm{N}$ & 89 & 89 & 89 & 89 & 89 \\
\hline \multirow{4}{*}{$\begin{array}{l}\text { Final } \\
\text { course } \\
\text { score }\end{array}$} & $\begin{array}{l}\text { Pears } \\
\text { on }\end{array}$ & .137 & .122 & 1 & $.229 *$ & .881 \\
\hline & $\begin{array}{l}\text { Correl } \\
\text { ation }\end{array}$ & & & & & \\
\hline & $\begin{array}{l}\text { Sig } \\
(2- \\
\text { tailed) }\end{array}$ & .199 & .255 & & .031 & .000 \\
\hline & $\mathrm{N}$ & 89 & 89 & 89 & 89 & 89 \\
\hline \multirow[t]{4}{*}{$\begin{array}{l}\text { Online } \\
\text { score }\end{array}$} & $\begin{array}{l}\text { Pears } \\
\text { on }\end{array}$ & $.506^{* * *}$ & $.402 * *$ & $\begin{array}{r}.229 \\
* \\
\end{array}$ & 1 & $\begin{array}{r}.518 \\
* * \\
\end{array}$ \\
\hline & $\begin{array}{l}\text { Correl } \\
\text { ation }\end{array}$ & & & & & \\
\hline & $\begin{array}{l}\text { Sig } \\
(2- \\
\text { tailed) }\end{array}$ & .000 & .000 & .031 & & .000 \\
\hline & $\mathrm{N}$ & 89 & 89 & 89 & 89 & 89 \\
\hline \multirow[t]{4}{*}{$\begin{array}{l}\text { Final } \\
\text { grade }\end{array}$} & $\begin{array}{l}\text { Pears } \\
\text { on }\end{array}$ & $.348 * *$ & $.298 * *$ & $\begin{array}{r}.881 \\
* *\end{array}$ & $\begin{array}{r}.518 * \\
*\end{array}$ & 1 \\
\hline & $\begin{array}{l}\text { Correl } \\
\text { ation }\end{array}$ & & & & & \\
\hline & $\begin{array}{l}\text { Sig } \\
(2- \\
\text { tailed) }\end{array}$ & .001 & .005 & .000 & .000 & \\
\hline & $\mathrm{N}$ & 89 & 89 & 89 & 89 & 89 \\
\hline
\end{tabular}

There is a positive correlation between the number of posts and online tutorial scores $(r=0.506$, $\mathrm{p}$-value $0.01)$, and the number of posts with the final grade ( $\mathrm{r}=$ 0.348 , p-value 0.01 ). However, the number of posts does not correlate significantly with the final course scores. The positive correlation of the number of posts and online tutorial score indicates that the focus of online tutorial caters both for course substance as well as the learning process in developing collaboration and interaction between participating students. Those who are actively posting during the collaboration assignments reach completion and score better in the course assignment which leads to a better tutorial online score. The assignments in these two tutorial modes are different, and also the tutors who mark the assignments are different.

\subsubsection{Student performance by gender}

It is interesting to note whether there is a difference between males and females in terms of performance. As seen from Table 4, there is a five-point difference in the average score of male and female students for the online tutorial $(62.05 ; 74.39)$. 
Table 4. Descriptive statistics of learning outcomes by gender

\begin{tabular}{llrrr}
\hline Gender & & $\begin{array}{l}\text { Final } \\
\text { Score }\end{array}$ & $\begin{array}{l}\text { Online } \\
\text { score }\end{array}$ & \multicolumn{1}{c}{$\begin{array}{l}\text { Final } \\
\text { grade }\end{array}$} \\
\hline Male & Mean & 78.1500 & 62.0500 & 79.2350 \\
& N & 20 & 20 & 20 \\
& Std. & & & \\
& Deviation & 6.63940 & 27.45230 & 8.36276 \\
\hline \multirow{2}{*}{ Female } & Mean & 81.9783 & 74.3913 & 82.8210 \\
& N & 69 & 69 & 69 \\
& Std. & & & \\
& Deviation & 12.05729 & 19.42044 & 11.51128 \\
\hline \multirow{2}{*}{ Total } & Mean & 81.1180 & 71.6180 & 82.0152 \\
& N & 89 & 89 & 89 \\
& Std. & & & \\
& Deviation & 11.15516 & 21.93146 & 10.94346 \\
\hline & & & & \\
& & & &
\end{tabular}

Table 5 shows that the online tutorial score was statistically different between male and female students $(p=0.26)$. The final course score and course grade are not significantly different. In the online tutorial, women obtained a higher average score and a 12 point difference than their male counterparts, which is significantly different ( $p$-value .026). This may be because women are more detailed and thorough in carrying out tasks.

Table 5. Analysis of ANOVA learning outcomes by Gender

\begin{tabular}{|c|c|c|c|c|c|c|}
\hline & & $\begin{array}{l}\text { Sum of } \\
\text { Square }\end{array}$ & df & $\begin{array}{l}\text { Mean } \\
\text { Square }\end{array}$ & $\mathrm{F}$ & Sig \\
\hline \multicolumn{7}{|l|}{ Final } \\
\hline Course & Between & & & & & \\
\hline Exam* & Groups & & & & & \\
\hline \multirow[t]{4}{*}{ Gender } & (Combined) & 227.244 & 1 & 227.244 & 1.844 & .178 \\
\hline & Within & & & & & \\
\hline & Groups & 10723.267 & 87 & 123.256 & & \\
\hline & Total & 10950.511 & 88 & & & \\
\hline \multirow{6}{*}{$\begin{array}{l}\text { Online } \\
\text { Score* } \\
\text { Gender }\end{array}$} & Between & & & & & \\
\hline & Groups & & & & & \\
\hline & (Combined) & 2361.626 & 1 & 2361.626 & 5.141 & .026 \\
\hline & Within & & & & & \\
\hline & Groups & 39965.385 & 87 & 459.372 & & \\
\hline & Total & 42327.011 & 88 & & & \\
\hline \multirow{6}{*}{$\begin{array}{l}\text { Final } \\
\text { Grade* } \\
\text { Gender }\end{array}$} & Between & & & & & \\
\hline & Groups & & & & & \\
\hline & (Combined) & 199.394 & 1 & 199.394 & 1.678 & .199 \\
\hline & Within & & & & & \\
\hline & Groups & 10339.428 & 87 & 118.844 & & \\
\hline & Total & 10538.823 & 88 & & & \\
\hline
\end{tabular}

\subsubsection{Student performance by place of origin}

Table 6 shows that there are significant differences in the number of posts in the tutorial online by place of student origin/location $(\mathrm{p}$-value $=0.005)$ but not significant in terms of access (p-value 0.263 ) and the online tutorial online score $(p$-value $=0.574)$. Significant differences in the number of posts may indicate variations in the reliability of internet signals between regions of Indonesia because posting will require time to read other student posts and to think of a good response. On the other hand, a significant difference may also indicate the level of readiness to interact in an online tutorial. Posting opinions in an 'open' forum discussion needs 'courage' and confidence that their opinions will be appreciated and well-received by other students. Some do not want to be considered "less intelligent" by other students. Regional differences seem to influence course end score and course grade. This finding will need to be further explored and clarified to identify the dynamics of regionalism and the intensity of online participation.

Table 6. Student engagement in the learning process and learning outcomes by place of origin

\begin{tabular}{|c|c|c|c|c|c|c|}
\hline & & $\begin{array}{c}\text { Sum of } \\
\text { Squares }\end{array}$ & df & $\begin{array}{c}\text { Mean } \\
\text { Square }\end{array}$ & $\mathrm{F}$ & Sig \\
\hline \multirow[t]{3}{*}{$\begin{array}{l}\text { Number } \\
\text { of } \\
\text { posting * } \\
\text { Place of } \\
\text { origin }\end{array}$} & $\begin{array}{l}\text { Between } \\
\text { Groups } \\
\text { (Combined) }\end{array}$ & 1266.029 & 8 & 158.254 & 3.013 & .005 \\
\hline & $\begin{array}{l}\text { Within } \\
\text { Groups }\end{array}$ & 4202.375 & 80 & 52.530 & & \\
\hline & Total & 5468.404 & 88 & & & \\
\hline \multirow[t]{3}{*}{$\begin{array}{l}\text { Number } \\
\text { of access } \\
* \text { Place } \\
\text { of origin }\end{array}$} & $\begin{array}{l}\text { Between } \\
\text { Groups } \\
\text { (Combined) }\end{array}$ & 70001.769 & 8 & 8750.221 & 1.286 & .236 \\
\hline & $\begin{array}{l}\text { Within } \\
\text { Groups }\end{array}$ & 544262.231 & 80 & 6803.278 & & \\
\hline & Total & 614264 & 88 & & & \\
\hline \multirow[t]{3}{*}{$\begin{array}{l}\text { End } \\
\text { course } \\
\text { score } * \\
\text { Place of } \\
\text { origin }\end{array}$} & $\begin{array}{l}\text { Between } \\
\text { Groups } \\
\text { (Combined) }\end{array}$ & 2820.839 & 8 & 352.605 & 3.470 & .002 \\
\hline & $\begin{array}{l}\text { Within } \\
\text { Groups }\end{array}$ & 8129.672 & 80 & 101.621 & & \\
\hline & Total & 10950.511 & 88 & & & \\
\hline \multirow[t]{3}{*}{$\begin{array}{l}\text { Online } \\
\text { score * } \\
\text { Place of } \\
\text { origin }\end{array}$} & $\begin{array}{l}\text { Between } \\
\text { Groups } \\
\text { (Combined) }\end{array}$ & 3264.613 & 8 & 408.077 & .836 & .574 \\
\hline & $\begin{array}{l}\text { Within } \\
\text { Groups }\end{array}$ & 39062.398 & 80 & 488.280 & & \\
\hline & Total & 42327.011 & 88 & & & \\
\hline \multirow[t]{3}{*}{$\begin{array}{l}\text { Course } \\
\text { grade } * \\
\text { Place of } \\
\text { origin }\end{array}$} & $\begin{array}{l}\text { Between } \\
\text { Groups } \\
\text { (Combined) }\end{array}$ & 2637.495 & 8 & 329.687 & 3.338 & .002 \\
\hline & $\begin{array}{l}\text { Within } \\
\text { Groups }\end{array}$ & 7901.328 & 80 & 98.767 & & \\
\hline & Total & 10538.823 & 88 & & & \\
\hline
\end{tabular}

\subsection{Perceptions of collaborative online learning process}

The design of a collaborative online learning model is intended to provide opportunities for students to 
communicate and collaborate in groups, online. As stipulated by Maurino (2007), communication and learning systems which are adequate for distance education are positive when students can communicate intensely with instructors and other students. The ten questions in the questionnaire focused on team's communication and collaboration aspects which include: target and work mechanism, team strategy, communication, freedom of expression, division of tasks, and quality of work, team decisions, smooth workflow, individual contribution, and level of satisfaction. The results of each aspect are highlighted as follows. In Table 7 , the Mean of the 10 aspects of communication and collaboration between team members in carrying out collaborative tasks is seen.

Table 7. Means of the teams' collaboration aspects

\begin{tabular}{llcc}
\hline \multirow{2}{*}{ No } & \multicolumn{2}{c}{ Team Aspects } & \multicolumn{2}{c}{ Means } \\
\cline { 2 - 4 } & & T1 & T2 \\
\hline 1 & Targets and working & & \\
& mechanism & 4,40 & 4,00 \\
2 & Team strategy & 4,03 & 4,10 \\
3 & Team communication & 3,90 & 3,97 \\
4 & Freedom of expression & 4,50 & 4,37 \\
5 & Division of tasks & 4,23 & 4,23 \\
6 & Quality of work & 4,13 & 4,23 \\
7 & Team decision & 4,47 & 4,33 \\
8 & Smooth work flow & 4,20 & 4,27 \\
9 & Contribution & 4,17 & 4,40 \\
10 & Satisfaction & 4,17 & 4,20 \\
\hline
\end{tabular}

From Table 7, it shows that with means of two measurement times, some aspects increased, namely: team strategy, team communication, team's quality, teams working smoothly, team contribution, and team's satisfaction, while some aspects decreased, namely teams' targets and mechanism, team's opinions, and team's decisions.

\subsubsection{Experience of team collaboration}

In collaborative online learning, several respondents stated that the experience of collaboration was positive. The following are some of the respondents' statements related to the collaboration experience they had from collaborative online learning. "Collaborative learning gives a lot of experience, especially to train cohesiveness among group members who don't know each other. It's amazing that you can get to know each other and exchange ideas" (QA, K1, 2018).

The opinions of respondents related to the collaborative task showed the importance of the team's cooperation in the process of completing the task. This was also observed by Tracey (2015) that collaborative process and product design in teams was carried out through the presentation of ideas, discussions, improvements, and also consensus. Many respondents argue that collaborative online learning helped them for a better understanding of the learning material related to collaborative tasks. The opinions of respondents such as "Collaborative activities have many benefits, increase understanding of the material, can learn to socialize, can develop thinking and communication skills" (BNV, K2, 2018). Collaborative learning, where students must work in teams led by a chairperson, also provides additional experience in terms of leadership, as stated by respondents "My involvement was quite intense because I was appointed as chairman, making me very motivated to do the job properly" (EWC, K1, 2018)

\subsubsection{Constraints}

In addition to the positive opinion conveyed by students, there are also several obstacles and losses felt by students in the process of collaborative activities. In the process of completing the collaboration tasks, some students seem to face obstacles in communicating and coordinating. Some of the efforts made by students to overcome the barrier in team's communication include the following: communicate via messenger, create a WhatsApp (WA) group, be more active in the online tutorial, more actively invite other members to discuss, contact tutor via email to help them to deal with group problems, remind each other to do their part of assignments. The students' effort in completing the collaborative tasks are quite interesting. This can be presented as notes for implementing collaborative online learning. "The difficulty is when communicate with group members, so we create WhatsApp (WA) groups to facilitate our communication" (MU, K1, 2018)

\section{CONCLUSION}

Based on the data from the open questions, it appeared that there were inconsistencies regarding the results from the online questionnaire in terms of communication and coordination between team members. The results of the online questionnaire indicate that team communication and coordination went well, while the results of open question data showed some issues with communication and coordination among team members. It is possible for students not to be open with evaluating their team members through online questionnaires.

In addition to the aspects of communication and coordination among group members, another important thing to consider is to improve the design of collaborative online learning. There is a need for clearer and more detailed instructions. As such, all students can have a comprehensive understanding of completing team tasks. Most students thought that the assignments in collaborative online learning in the "Education Diffusion 
and Innovation course" were harder compared to other courses. Nevertheless, students considered that the collaborative assignments were very challenging and interesting because they allowed them to share their insights and collaborate in smaller groups and this could even become a characteristic of postgraduate programs.

To conclude, collaborative learning in UT's online tutorials is a new design that needs to be tried and tested as one of the online tutorial's models. For this reason, it is necessary to explore various collaborative online learning models that are being implemented, so that students can get the full benefit from them. As a new model, collaborative online learning was well-received by students, even though they needed time to adjust to the collaboration and intensive communication phases to complete their assignments and secure a good grade. The collaborative learning model in the online tutorial intends to provide a medium for students to communicate more intensively with other students in small groups. This model is expected to develop teamwork and participation, which focus on 'non-cognitive skills' which are in great demand by everyone in the modern times, to develop oneself and live in the modern society.

\section{REFERENCES}

[1] M.F. Brereton, D.M. Cannon, A. Mabogunje, L.J Leifer, Collaboration in design teams: How social interaction shapes the product, in: N. Cross, H. Christiaans, K. Dorst (Eds.), Analyzing Design Activity, Chichester, England, Wiley, 1996, pp. 319341.

[2] L.J.Chalin, Y.T Chen, K.C. Chan, "Labeled Postings for Asynchronous Interaction," AACEJ, vol 17, no.4, pp.317-332, 2009.

[3] M.M. Cristopher, J.A.Thomas, \& M.K. TallentRunnels, Raising the bar: Encouraging high-level thinking in online discussion forums. Roeper Review, vol.26, no.3, pp. 166-17, 2004.

[4] S. Dawson, "A study of the Relationship between Student Social Networks and Sense of Community,".J.of Educ. Technol. \& Society, vol.11, no.3, pp.224-238, 2008.

[5] J.V. Dempseh, R.N. Van Eck, E-learning and instructional design, in: R.A. Reiser \& J.V. Dempsey (Eds.), Trends and Issues in Instructional Design and Technology Boston: Pearson Education Inc, 2012, pp.281-289.

[6] P. Dillenbourg, Over-scripting CDCL: The risks of blending collaborative learning with instructional design, in: P.A. Kirschner (Ed.), Three Worlds of CSCL. Heerlen: Open Universitat Nederland, 2002, pp. 61-91.

[7] K.M. Gibson, "Fostering Collaboration and Learning in a Asynchronous Online Environments," Journal of Teaching and Learning with Technology, vol.2. no.2, pp.60-78, 2013.
[8] M. Lister, "Trends in the Design of E-learning and Online Learning," Journal of Online Learning and Teaching, vol.10, no. 4, pp.671-680, 2014.

[9] C. Luhrs, L.M. Salas, "Collaboration Levels in Asynchronous Discussion Forums: a Social Network Analysis Approach," Journal of Interactive Online Learning, vol.14, no.1, pp.2944, 2016.

[10] P.S.M. Maurion, "Online Asynchronous Threaded Discussions: Good Enough to Advance Students Through the Proximal Zone Activity Theory?," Tech Trends, vol.51, no.2, pp.46-49, 2007.

[11] A.Powell, J. Galvin, G. Piccoli, "Antecedents to Team Member Commitment from near and Far: A Comparison between Collocated and Virtual Teams," Information Technology \& People, vol.19, no.4, pp.299-322, 2006.

[12] M. Simonson, S. Smaldino, M. Albright, \& S. Zvacek, "Teaching and learning at a distance: Foundation of distance education," Boston, Pearson, 2012.

[13] M.W. Tracey, Design team collaboration with a complex design problem, in: B. Hokanson, G. Clinton, \& M.W. Tracey (Eds). The Design of Learning Experience, Switzerland, Springer, 2015, pp.93-108.

[14] Y. Wang," Internet Uses in University Courses," Int. J. of E-Learn, vol.6, no.2, pp.279-292, 2007. 